CURRENT RESEARCH JOURNAL OF PHILOLOGICAL SCIENCES 2(12):

45-48, December 2021

DOI: https://doi.org/10.37547/philological-crjps-02-12-09

ISSN 2767-3758

(C2021 Master Journals

Crossref dol

81 Google

Accepted06 ${ }^{\text {th }}$ December, 2021 \& Published 11 $1^{\text {th }}$ December, 2021

\title{
HISTORY OF CREATION "SHAH-NAME" FIRDOUSI
}

\author{
Madina A. Choriyeva
}

Lecturer Bukhara State Medical Institute Bukhara, Uzbekistan

\section{ABSTRACT}

The name of Ferdousi and his heritage, both creative and the legends about him, are a cultural code that plays an important role in the unity of the Persian cultural space, extending far beyond Iran. And at the same time the author of "Shahnameh" became a romantic legend of the West. The image of the poet, who created the greatest work, but did not receive recognition during his lifetime, turned out to be very close to European romantics. As well as the theme of the struggle against tyrants and autocrats, therefore, in many interpretations, Ferdousi appears not only as an unrecognized genius, but also as a victim of persecution.

KEYWORDS: - Epic poem, Iranian antiquity, couplet, primitive Indo-Aryan society, era of Arshakids, in Avesta Fragrasyan, the great epic of humanity

\section{INTRODUCTION}

Ferdousi (full name - Hakim Abulkasim Mansur Hasan Ferdousi Tusi) is traditionally considered the founder of Persian epic poetry. Today he is considered a national poet in Iran, Tajikistan, Uzbekistan and Afghanistan. Ferdousi is the author of the largest epic poem

Translated from Persian "Book of Kings", "Book of Kings", "King-Book". The Book of Kings describes the history of Iran from ancient times to the penetration of Islam in the 7th century. Shah Nam describes the history of more than 50 kingdoms.
60,000 bayts "Shah-Name" made up a single epic the longest poem ever written by a human hand. It covers the entire history of the Persian kingdoms for four millennia, contains the wisest sayings about love and separation, life and death.

\section{THE MAIN RESULTS AND FINDINGS}

At the beginning of the $\mathrm{X}$ century. favorable conditions were formed for the development of literature in the relatively centralized eastern Iranian state of the Samanids (887-999), independent of the Arab Caliphate, in which the country's economic structure was finally acquiring feudal forms. Crafts, local and caravan trade are 
CURRENT RESEARCH JOURNAL OF PHILOLOGICAL SCIENCES 2(12):

45-48, December 2021

DOI: https://doi.org/10.37547/philological-crjps-02-12-09

ISSN 2767-3758

(C)2021 Master Journals

Crossref do

81 Google

Accepted06 ${ }^{\text {th }}$ December, 2021 \& Published $11^{\text {th }}$ December, 2021

especially developed; culture is on the rise. Bukhara becomes not only the capital of this state, but also the center of the cultural life of the whole Eastern Iran and Central Asia. It was in Bukhara that the first large school of poetry and prose in Farsi took shape and flourished. The legacy of this school became a classic tradition for the subsequent development of literature.

In the domains of the Samanids, connoisseurs of the elegant word appear, the court encourages high poetry in Farsi. The poet responds to everything that could interest the newly revived Iranian aristocracy. The loss of connection with the ancient Iranian literary tradition and the centuries-old imitation of Arabic poetry during the period of the dominance of the Arabic language as the state, scientific and literary language in Iran led, obviously, to the fact that by the time of the emergence of poetry in the Farsi language, the Arabic quantitative principle of metric was strengthened to an ever-increasing degree, as in theory, and in practice

During the reign of the Samanids, interest in Iranian antiquity was revived, in particular, collections of legends and traditions about mythical and historical heroes and kings who lived before the Arab invasion were compiled in Farsi. These mythological codes are usually called "Shah-name" ("The Book of Kings").

Under the Sassanids, there was a book about kings in the Middle Persian (Pahlavian) language "Hvatai-namak", the text of which has not reached us. There is evidence of the compilation of at least four works that have not come down to us in the Farsi-Dari language: this is the prosaic "Shah-name" of Abu-l-Muayyad Balkhi (963); "Shah-name" by Abu Ali Muhammad ibn Ahmad Balkhi; "Shahname" by Masud-i Marvazi (compiled earlier in 966) and, finally, "Mansurova Shah-name" (dedicated to Mansur), completed in 957. It was this work that Ferdowsi used in his work. The preface to "Mansurova Shah-nama" with pronounced features of early Persian-language prose came to light. The authors of this epic collection apparently used oral tradition, legends that existed in the folk and dekhkan (petty feudal) environment. One of the authors was Dakiki (d. 977), who probably knew all these works.

The Dakiki court poet brought together the myths that later served as the basis for Shah Nama. After preliminary work, Dakiki began compiling his poetry book. According to some reports, he managed to write about 5,000 bytes. The poet's unexpected death at the hands of a slave during a feast interrupted his work, and Ferdousi included only about a thousand of his beits in his "ShahNama". They have come down to us, revealing, like other poetic fragments of Dakiki, the author's sympathy for ancient traditions and the Zoroastrian faith.

Ferdousi wrote to Shahnameh for 35 years. During this time, the political situation in the country has changed dramatically. The ruling Samanid dynasty was replaced by Sultan Mahmud, a Turk by origin. This created a number of difficulties for Ferdousi. Shah Nam is a purely Iranian poem that glorifies Iranian culture and the Iranian people, placing Iran at the center of the universe. The main idea of the poem is that only hereditary carriers of royal power have the right to it. Naturally, such a poem could not please the new government. Sultan Mahmud was more satisfied with the idea of the legitimacy of force, and not heredity. According to a well-known legend, which does not have precise confirmation, the sultan refused to pay Ferdousi for the poem. This greatly angered the poet, and he wrote a satire in which he reproached the Sultan for descent from a slave. As a result of the Sultan's wrath, Ferdousi was forced to flee the country and wander in 
CURRENT RESEARCH JOURNAL OF PHILOLOGICAL SCIENCES 2(12):

45-48, December 2021

DOI: https://doi.org/10.37547/philological-crjps-02-12-09

ISSN 2767-3758

(C)2021 Master Journals

Crossref do

81 Google

Accepted06 ${ }^{\text {th }}$ December, 2021 \& Published $11^{\text {th }}$ December, 2021

poverty for the rest of his life. Another legend was poetically adapted by the great German romantic Heinrich Heine, according to which the Sultan promised the poet to pay a gold coin for each couplet. But Mahmoud deceived him cruelly. When a caravan from the Sultan arrived and the bales were untied, it turned out that gold had been replaced by silver. The offended poet, who, according to legend, was in a bathhouse, divided this money into three parts: he handed one to the attendant, the other to the people of the caravan, and in the third he bought soft drinks. It was a clear and direct challenge to an oppressive ruler. The Sultan ordered to punish the poet - to throw him at the feet of the elephant. Ferdousi fled his native land and spent many years wandering. Only in old age did he decide to return to his homeland. Once the chief minister, in the presence of Mahmoud, recited a couplet from a great poem. The Sultan, having replaced his anger with mercy, decided to reward the poet. When the caravan with gifts entered the gates of the city, a stretcher with the body of the deceased Ferdousi was carried out from the opposite gates.

The name of Ferdousi and his heritage, both creative and the legends about him, are a cultural code that plays an important role in the unity of the Persian cultural space, extending far beyond Iran. And at the same time the author of "Shahnameh" became a romantic legend of the West. The image of the poet, who created the greatest work, but did not receive recognition during his lifetime, turned out to be very close to European romantics. As well as the theme of the struggle against tyrants and autocrats, therefore, in many interpretations, Ferdousi appears not only as an unrecognized genius, but also as a victim of persecution.

One of the most famous works of this kind is Hans Christian Andersen's essay "The Thorny Path of Glory." The author puts Ferdousi on a par even not with poets, but with great scientists and discoverers, from Columbus to Tycho Brahe and Robert Fulton, on a par with statesmen.

\section{Conclusion}

Heinrich Heine put into verse that version of the legend, according to which at first Ferdousi received a very meager reward, and not in gold, as he hoped after hearing the ruler's promise to pay a coin per line, but in silver. In annoyance, he gives money to the bathhouse attendant and the Shah's messengers, and he himself leaves to wander. Then he returns and lives in Tus, courting his modest garden, not knowing that his poem has already become known to the people and loved.

Ferdousi was buried in Tus, and his tombstone was very modest for a long time. The now existing mausoleum of white marble, very similar to the tomb of Cyrus the Great in Pasargadae, was erected to commemorate the 1000th anniversary of the poet. On the walls of the mausoleum, fragments from the poem "Shahnameh" are inscribed in traditional nastalik calligraphic handwriting. Inside and outside, there are bas-reliefs and sculptures depicting key episodes of the poem.

\section{REFERENCES}

1. Xuseynova, А. (2020). РОЛЬ ЖЕНЩИН В СОЦИАЛЬНО-ПОЛИТИЧЕСКОЙ ЖИЗНИ ОБЩЕСТВА. ЦЕНТР НАУЧНЫХ ПУБЛИКАЦИЙ (buxdu. uz), 1(1).

2. Хусейнова, А. А. (2017). ФИЛОСОФСКОЕ МИРОПОНИМАНИЯ АБДУРАХМАНА ДЖАМИ. Ученый XXI века, 88.

3. Чориева, М. А. (2020). Экономика и денежное обращение (монеты) в Бухарском эмирате при мангытах (на рубеже 19-20 веков). Наука, техника и образование, (5 (69)), 53-56. 
CURRENT RESEARCH JOURNAL OF PHILOLOGICAL SCIENCES 2(12):

45-48, December 2021

DOI: https://doi.org/10.37547/philological-crjps-02-12-09

ISSN 2767-3758

(C)2021 Master Journals

Crossref dof 81 Google

Accepted06 ${ }^{\text {th }}$ December, 2021 \& Published 11 th December, 2021

4. Ахмедова, 3. А., \& Чориева, М. А. (2020). ТРУД АХМАДА ДОНИША «ИСТОРИЯ МАНГИТСКИХ ГОСУДАРЕЙ» КАК ЦЕННЫЙ ИСТОЧНИК ПО ИСТОРИИ БУХАРСКОГО ХАНСТВА ВТОРОЙ ПОЛОВИНЫ ХVIIIПЕРВОЙ ПОЛОВИНЫ XIX ВВ. Наука, техника и образование, (11 (75)).

5. Чориева, М. А. (2020). СОЦИАЛЬНОЭКОНОМИЧЕСКОЕ, ПОЛИТИЧЕСКОЕ ПОЛОЖЕНИЕ БУХАРСКОГО ЭМИРАТА В КОНЦЕ XIX ВЕКА. Наука, техника и образование, (11 (75)).

6. Azizovna, A. Z. (2021). THE ROLE OF TEACHING PHILOSOPHY IN MEDICAL UNIVERSITY. Наука, техника и образование, (6 (81)), 44-48.

7. Ахмедова, 3. А. (2018). Астрономические взгляды Ахмада Дониш. Вестник науки и образования, (11 (47)).

8. Ахмедова, 3. А. (2020). HUMAN BEING IN THE WORKS OF MEDIEVAL THINKERS. Новый день в медицине, (4), 115-118.

9. Ахмедова, 3. А. (2021). ХІХ АСРНИНГ ИККИНЧИ ЯРМИДА ТУРКИСТОН ЎЛКАСИ МАДАНИЯТИ. ВЗГЛЯД В ПРОШЛОЕ, 4(7).

10. Сагикызы, А., Шуршитбай, М., \& Ахмедова, 3. (2021). UPBRINGING AND EDUCATION AS FACTORS OF HUMAN CAPITAL DEVELOPMENT. Адам әлемі, 88(2), 18-25.

11. Ахмедова, 3. А., \& Турсунов, К. С. (2020). Интеграционный процесс в рамках Европейского союза. Наука, техника и образование, (5 (69)), 49-52.

12. Стариков А.А. Фирдоуси и его позма "Шахнаме".-Фирдоуси. Шах-намс, т.1.-М.:Наука, 1957, c.529-530. 